\title{
A MEGYEI JOGÚ VÁROSOK ÁTFOGÓ GAZDASÁGFEJLESZTÉSE A MODERN VÁROSOK PROGRAMON KERESZTÜL, KÖZÉPPONTBAN AZ INFRASTRUKTÚRA-FEJLESZTÉS
}

THE ECONOMIC DEVELOPMENT OF THE CITIES WITH COUNTY RIGHTS INTO THE MODERN CITIES PROGRAM FOCUSING OF THE INFRASTRUCTURE DEVELOPMENT

\section{Péli László PhD¹, Káposzta József CSc², Némediné Kollár Kitti PhD ${ }^{3}$}

\author{
${ }^{1,2}$ egyetemi docens, ${ }^{3}$ adjunktus \\ 1,2,3 Szent István Egyetem, Gazdaság- és Társadalomtudományi Kar, Regionális Gazdaságtani \\ és Vidékfejlesztési Intézet \\ E-mail: ${ }^{1}$ peli.laszlo@gtk.szie.hu, ${ }^{2}$ kaposzta.jozsef@gtk.szie.hu, ${ }^{3}$ kollar.kitti@gtk.szie.hu
}

\section{Összefoglalás}

A Modern Városok Program egy hatalmas mértékủ fejlesztési-támogatáscsomag, melynek során Magyarország Kormánya a megyei jogú városokat támogatja számos területen. A cél ezáltal, felpezsdíteni ezen városok gazdaságát, hogy azok valós centrumai lehessenek környező térségüknek. Fontos megjegyezni, hogy ezen gazdaságfejlesztési intézkedések alapja a megfelelő szintű elérhetőség, amely kedvező közlekedési infrastruktúrát igényel. Az általunk vizsgált program egyik pillére ennek biztosítása a vidéki nagyvárosok részére.

\begin{abstract}
In our days, one of the biggest challenge of both the developing and the developed world is the widening of territorial disparities - even in global dimension. The gap between the poor and the rich shows a rapid and continuous increase instead of shrinking or at least remain stagnant. The vast majority of the countries in our Earth are trying to combat against this phenomenon but unfortunately - with not much success. The same is typical of Hungary as well, the gap in terms of territorial disparities has still been widening. Furthermore Hungary has a peculiar situation as due to her historical antecedents, there is only one significant city which can be considered competitive in European context, this is Budapest, the capital city. The Modern Cities Program supports cities with county rights in order to improve their economic development which has positive effect on the settlements in their periphery.
\end{abstract}

Kulcsszavak: Modern Városok Program, megyei jogú város, területi különbségek, fejlesztési célú támogatás

JEL kód: R50, R58

LCC kód: H1-99

\section{Bevezetés}

Napjainkban a területi különbségek kiszélesedése globálisan is a fejlődő és fejlett világ egyik legnagyobb kihívását jelenti. A szegények és gazdagok közötti ür nemhogy csökkenne, hanem folyamatosan és rohamos tempóban növekszik. A világ országainak túlnyomó többsége küzd ezzel a jelenséggel, sajnos kevés sikerrel. Csakúgy, mint ezen országokra, Magyarországra is jellemző ez a területi különbségeket uraló egyre táguló szakadék. Magyarország ráadásul speciális helyzetben van, hiszen történelmi előzményei okán (trianoni békeszerződés) mindössze egyetlen jelentős, európai mértékben is versenyképes várossal rendelkezik, mégpedig a fövárossal: Budapesttel. Budapest és agglomerációja határozza meg a mai Magyarország gazdaságát, mivel a vidéki városok közül önmagában egyik sem elég erős ahhoz, 
hogy gazdasági decentrumként funkcionáljon a hazai térszerkezeten belül. Ehhez kapcsolódik a Magyarország Kormánya által 2015 márciusban meghirdetett "Modern Városok Program", melynek értelmében a megyei jogú városok fejlődése a vidék fejlődésének a záloga. Mint az 1. számú ábrán is látható Magyarországon 23 megyei jogú város található.

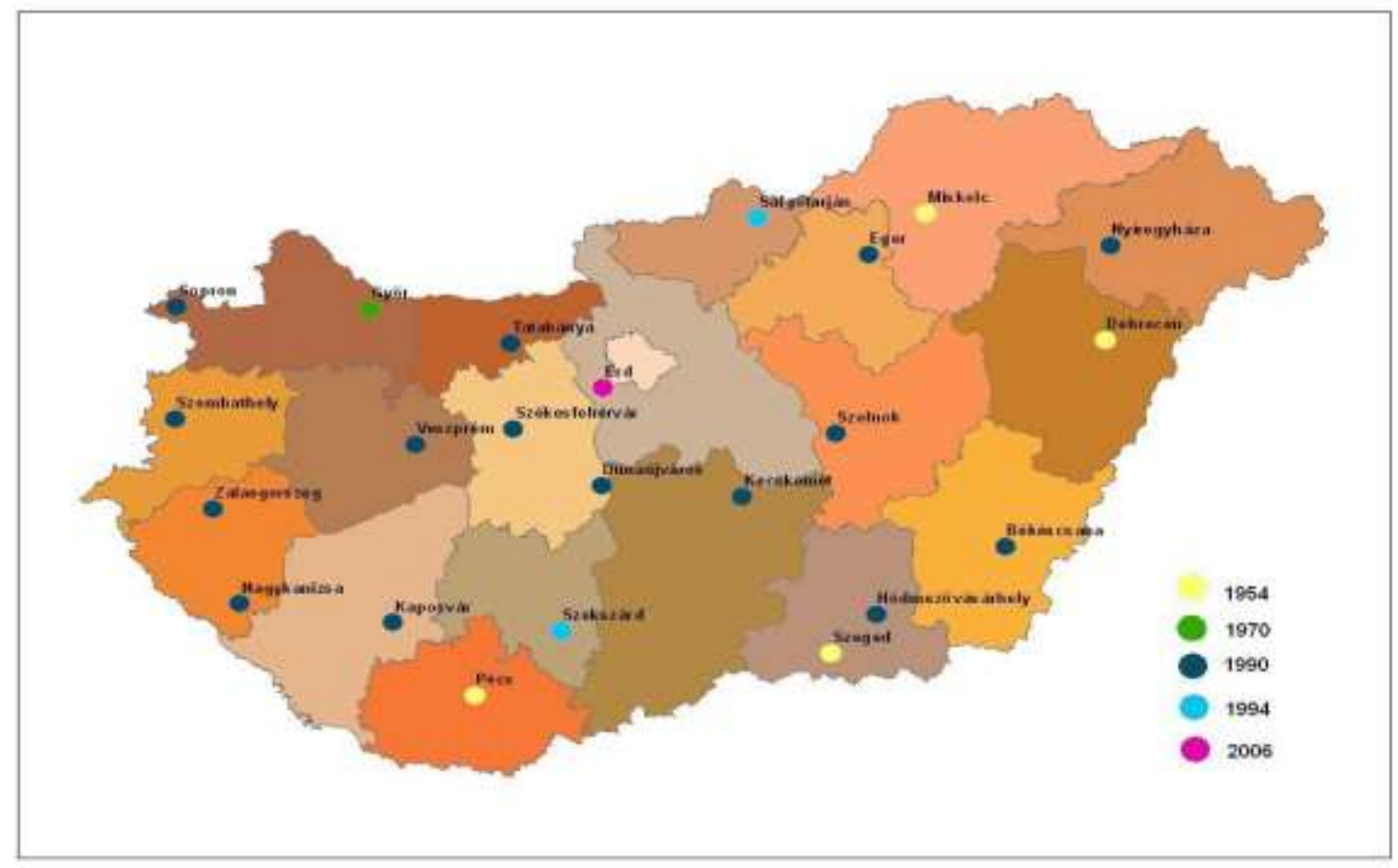

\section{1. ábra: A megyei jogú városok, megyei jogú várossá nyilvánításuk időpontja} szerint

Forrás: terport.hu, 2017

A Modern Városok Program keretében Magyarország Miniszterelnöke személyesen kereste fel a hazánkban található 23 megyei jogú várost, ahol egyeztetéseket folytatott a város gazdaságfejlesztési koncepciójáról, illetve a helyi vezetéssel megállapodtak a fejlesztésekhez szükséges forrásokról. Ezen források döntően gazdaságfejlesztési célt szolgálnak, de az egészség-, illetve sportfejlesztések éppúgy megtalálhatóak, mint az oktatás-, kultúra-, vagy idegenforgalmi fejlesztések. Bő két éve, 2015. március 25-én kezdődött a program, melynek első állomása Sopron városa volt, míg a sort Hódmezővásárhely városa zárta 2017. május 26án.

A program fő célja ezen vidéki városok gazdaságának megerősítése, azáltal, hogy a következő években a rendelkezésre álló fejlesztési forrásokat elsősorban a helyiek döntése alapján osszák szét.

Kutatásunkban megvizsgáljuk, hogy a Modern Városok Program a vidéki társadalom mekkora részére hat közvetlenül, illetve közvetetten a megyei jogú városok agglomerációjára, illetve a tőlük távolabb eső, periférikus területekre gyakorol-e hatást.

\section{Irodalmi áttekintés}

Magyarország térszerkezetét vizsgálva - a trianoni békeszerződésnek köszönhetően - a területfejlesztéssel foglalkozó szakirodalom egyöntetüen leszögezi, hogy hazánk alapvetően monocentrikus térszerkezetủvé vált, Budapest dominanciája az élet minden területén érvényesül (Beluszky, 2003; Oláh-Topa, 2016). A monocentrikus struktúra oldására tett kísérletek sem új keletűek, bár igazi jelentőségük a NUTS-rendszer kialakítása után teljesedett 
ki (Csomós, 2010), mikor a régióközpontok nagyobb önállóságot kaptak és mintegy ellensúly szerepet igyekeznek betölteni.

A regionális folyamatok szempontjából a XX. század hatalmas átalakulásokat eredményező utolsó évtizede nem tekinthető egységes időszaknak. A korszak első felét a korábbi rendszer struktúráinak leépülését kísérő krízisjelenségek uralták. A kilencvenes évek közepétől kezdve érzékelhetően megjelentek a megújulás (elsősorban makrogazdasági) jelei, a helyi és regionális siker csomópontjai (Nemes Nagy, 2005; Ritter, 2017). Ezalatt az évtized alatt az eddigi legjelentősebb társadalmi-gazdasági térszerkezeti átrendeződésnek lehettünk tanúi, gyökeresen megváltoztak az addigra kialakult állapotok.

Ésszerüen belátható, hogy a fóváros dominanciájának mérséklése nem annak érdemeinek megnyirbálásával lehetséges, hanem a hátrányosabb helyzetben lévő területek felzárkóztatásával, a közöttük meglévő különbségek kiegyenlítődésével valósítandó meg. Budapest - mint hazánk egyedüli, európai szinten is versenyképes metropoliszának gyengítésével az országon belüli polarizáció mérséklödik, viszont Európától - mint centrumterülettől - való elszakadásunk felerősödik (Péli, 2013).

A gazdasági növekedés mindig is érdekelte és érdekelni fogja a regionális gazdasággal foglalkozókat. Hiszen a regionális gazdaság növekedését meghatározó tényezők és az azok magyarázatára szolgáló összefüggések döntő hatással lehetnek a területi egyenlőtlenségek mérséklésére, azok okainak feltárására, kezelésére (Lengyel - Rechnitzer, 2004; ÁldorfaiCzabadai, 2014, Bakos-Gerencsér, 2016).

Kutatáshoz kapcsolódóan a regionális gazdasági növekedési modellek egyik fajtáját, a növekedési pólusok elméletét ismertetem. Rechnitzer és Lados (2004) alapján a növekedési pólusok modellje szerint a dinamikus ágazatokat tömörítő központok lényegében olyan növekedési pólusok, amelyek agglomerációs hatások útján növekedési hatást gyakorolnak a környezö településekre. A növekedési pólus maga egy centrumtelepülés.

A pólusok, nagyvárosok hálózatának jellemzője, hogy lakosságukra és az ingázókra építve meghatározó a szerepük a foglalkoztatásban, miközben a fővároson kívül a felsőoktatási, a kutatási tevékenységek, valamint a különösen nagy hozzáadott értéket előállító gazdaság koncentrációja jellemzi (ÚMFT, 2006).

A fejlesztési pólusok kialakításának célja, hogy meghatározott nagyvárosok olyan központokká váljanak, amelyek tartósan képesek erösíteni önmaguk és tágabb térségük (nemzetközi) versenyképességét. A fejlesztési pólusok harmonikus, egymással együttmüködő (város) hálózatok központjaiként egy policentrikus településrendszer elemeiként az ország egészének versenyképességét növelik. A pólusokhoz kapcsolódó fejlesztéseknek alapvetően négy funkcionális szintje különböztethető meg, amelyek közül az innovációs és gazdaságfejlesztő funkciók kapnak kiemelt szerepet.

A versenyképességi pólusok kialakításának feladata - a nemzetközi, elsősorban francia tapasztalatok alapján - 2004-ben fogalmazódott meg. A versenyképességi pólusok kialakítását megalapozó javaslatok már a kiemelt (stratégiai) fejlesztések keretében kerültek bemutatásra. A pólusként meghatározott városok francia metodika alapján kezdtek el dolgozni, és próbálták a pólus-gondolatot fejlesztési koncepcióikba, stratégiáikba beilleszteni. A magyar sajátosságok következtében (köztük az infrastrukturális hiányok, területfejlesztési és- felzárkóztatási szempontok) azonban az eredeti francia koncepciónak nemcsak a neve, hanem némileg a tartalma, illetve a program kivitelezésének módja, eljárásrendje is módosult (Salamin-Péti, 2005).

A magyarországi Pólus Program öt vidéki nagyvárost határozott meg, mely Budapest decentrumaiként müködhetnek. Ezt mutatja a 2. számú ábra. 


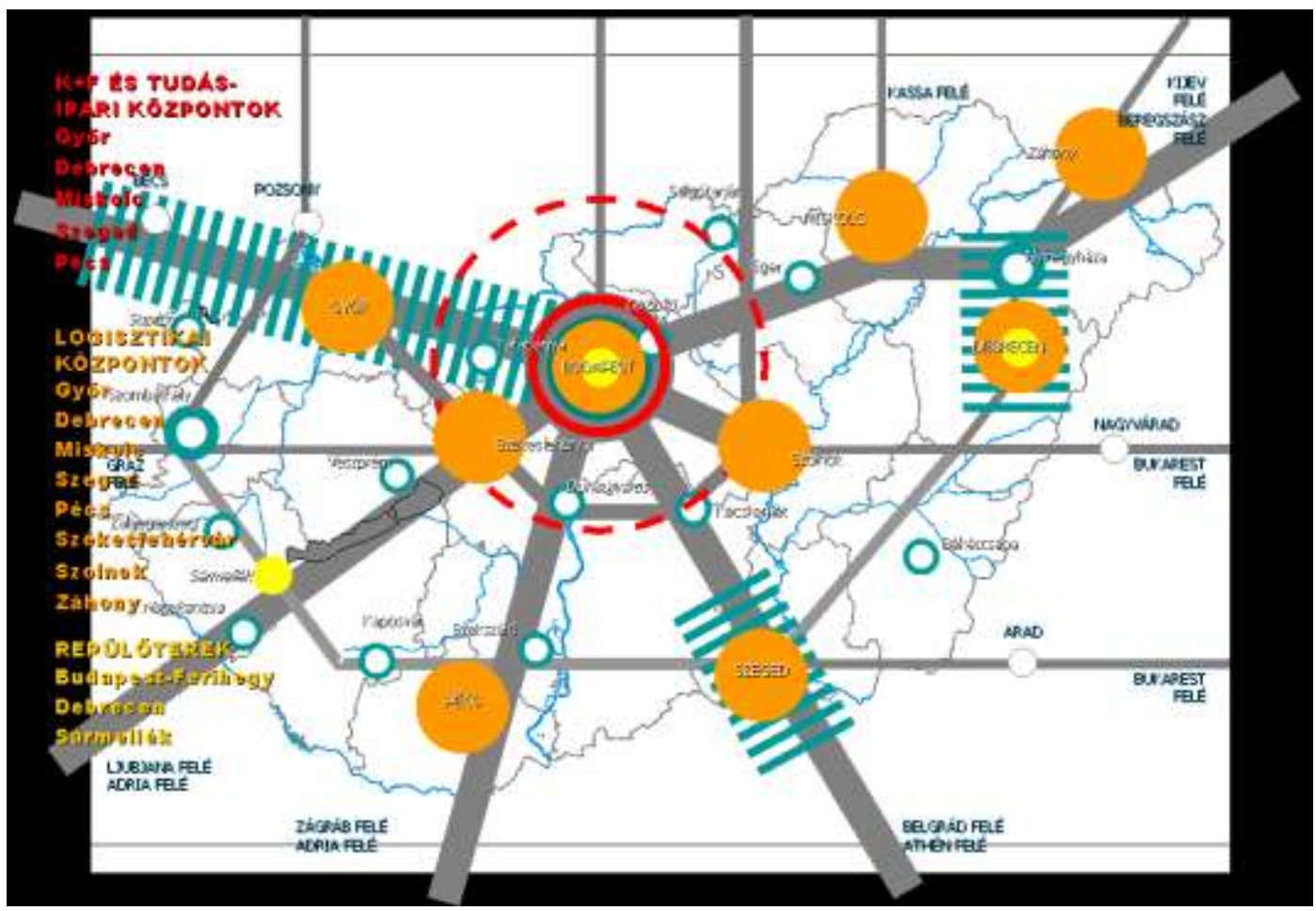

2. ábra: Magyarország távlati versenyképességi pólusai

Forrás: 96/2005. (XII. 25.) OGY határozat

A Programban deklarált öt növekedési pólus:

- Győr,

- Pécs,

- Szeged,

- Debrecen,

- Miskolc.

A program továbbfejlesztése során - francia mintára - meghatározták az egyes pólusok stratégia irányait, melyet a 3. számú ábrán szemléltetek:

- Budapest - INNOPOLIS: Budapest európai szintű központként történő megerősítése (MediPólus, ÖkoPólus, InfoPólus, MédiaPólus, TechnoPólus, EconoPólus)

- Győr - AUTOPOLIS: Jármügyártás, a beszállítói és logisztikai kapacitás fejlesztésével és a megújuló energiák hasznosításával

- Székesfehérvár-Veszprém - INFOPOLIS: Mechatronikai és elektronikai, média-, szoftver-, müanyagipari és logisztikai központ

- Miskolc - TECHNOPOLIS: Müszaki és gazdaságtudományi tudásbázisokra épülő, high-tech ipari megoldások, Mechatronika, Vegyipar, Anyagtudományok, Nanotechnológia

- Debrecen - „A TUDÁS IPAROSÍTÁSA”: Agrár-innováció, genetika, Európai Spallációs Neutronforrás megtelepítése

- Szeged - BIOPOLIS: Biotechnológiai kapacitásokra alapozott tudásintenzív fejlesztések, Szoftveripar fejlesztése

- Pécs - „AZ ÉLETMINŐSÉG PÓLUSA”: A kulturális ipar, az egészségipar és a környezetipar bázisán „szolgáltató pólus” kiépítése (Filep, 2008). 


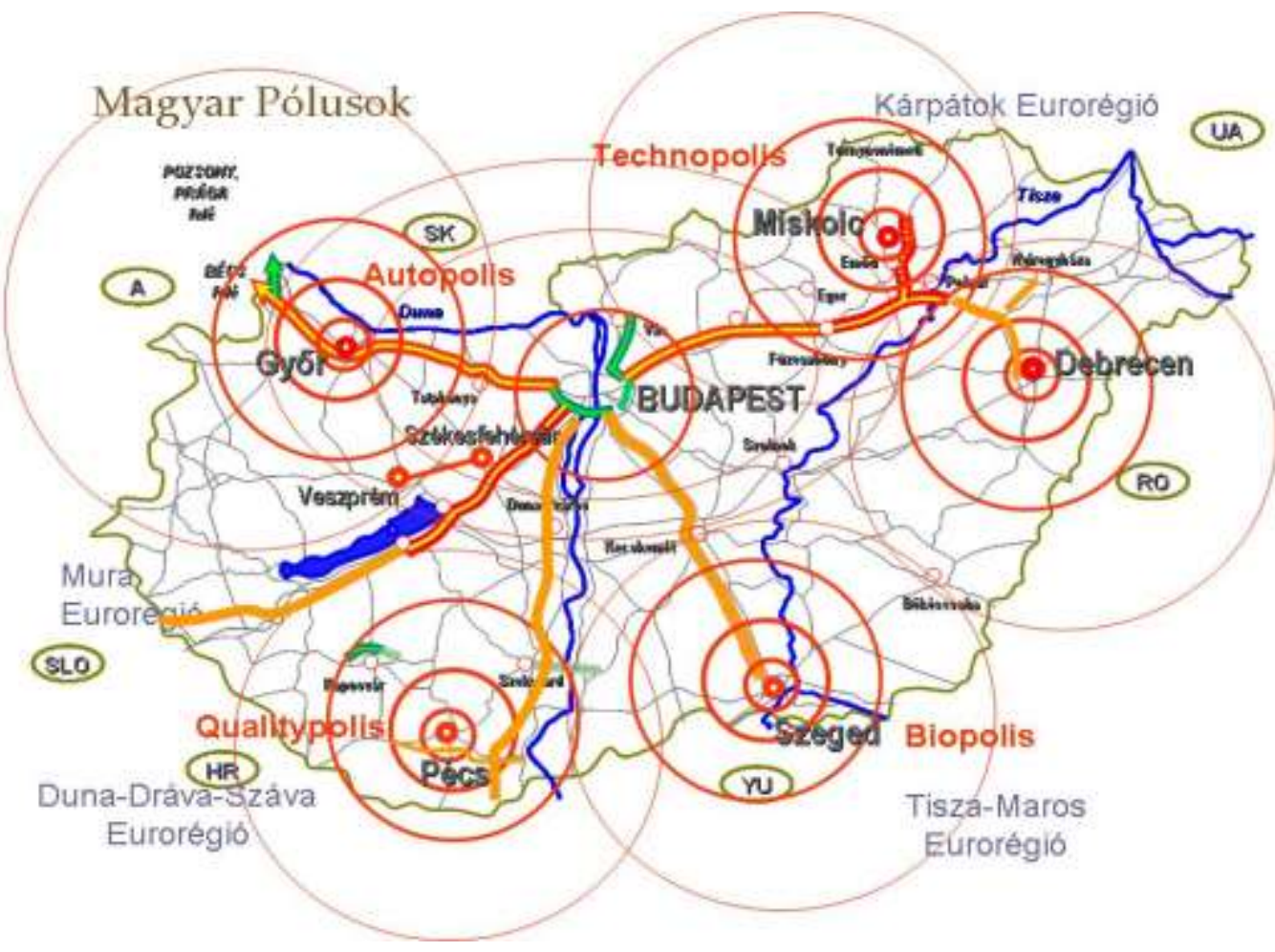

3. ábra: A hazai ,specializálódott” növekedési pólusok

Forrás: Gazdaságfejlesztési stratégia - Pécs Fejlesztési Pólus, 2012

Az elmélethez kapcsolódva született meg a jelenleg vizsgált Modern Városok Program, melynek értelmében ezek a megyei jogú városok lesznek a gazdasági fejlődés motorjai. Ennek hatására a fejlett centrum területek kedvező gazdasági hatást gyakorolnak a félperiférikus, illetve periférikus területekre, melynek köszönhetően megindul a nivellálódás.

\section{Anyag és módszer}

Kutatásunk alapját a Központi Statisztikai Hivatal évente gyüjtött területi adatai adják, melyeket a TeIR adatbázis biztosított számunkra. A kutatás során dokumentumelemzés, illetve adatelemzés módszerét alkalmaztuk. A Modern Városok Program bevezetése során Magyarország Kormánya együttmüködési megállapodást kötött a hazai 23 megyei jogú várossal. A megállapodások nyilvánosak, így azok tanulmányozása során összegyújtöttük a városoknak szánt források mértékét. A támogatások mértékét minden esetben az együttműködési megállapodások tartalmazzák, melyek 2015 és 2017 között köttettek. A TeIR adatbázisából pedig lekérdeztük az érintett városokra, illetve agglomerációjukra vonatkozó főbb adatokat, melyek 2015-ös adatok, hisz jelenleg ezek a legfrissebb elérhető adatok.

\section{A Modern Városok Program bemutatása}

Magyarország Kormánya 2015-ben jelentette be a - korábban nem látott mértékű támogatottságú - Modern Városok Programját. A támogatásban a magyarországi megyei jogú városok részesülnek. „Megyei jogú városok a megyeszékhelyek és azok az ötvenezernél nagyobb lakosságszámú városok, amelyeket az Országgyülés a képviselő-testület kérelmére ilyennek nyilvánít. A megyei jogú város települési önkormányzat, amely területén - megfelelő eltérésekkel - saját hatásköreként ellátja a megyei önkormányzati feladat- és hatásköröket is. Képviselö-testülete a közgyülés, amely a megyei jogú városban kerületeket alakíthat, és kerületi hivatalokat hozhat létre"(terport.hu, 2017). 
Megyei jogú város lehet, melynek népessége eléri az 50000 föt és az Országgyűlés - a képviselö-testület kérelmére - megyei jogú várossá nyilvánítja. Ezen felül minden megyeszékhely város automatikusan megyei jogú város is egyben.

Hazánkban jelenleg 23 megyei jogú város található, melyből 18 város megyeközpont is egyben. Azonban ezek a városok jogilag nem a megyék részei, hanem azzal azonos rangú közigazgatási egységek.

A Modern Városok Program egy 3400 milliárd forint értékü fejlesztési célú támogatáscsomag, mely magában foglal többek között:

- 690 km autópálya bővítést,

- 5 repülőtér fejlesztést,

- 1920 ha új ipari park létesítését,

- 170 mrd. Ft egészség- és sportcélú fejlesztést,

- 109 mrd. Ft oktatásfejlesztést (kormany.hu, 2017).

Mint az a fenti felsorolásból is látható, a program jelentős mértékü infrastruktúra-fejlesztést tartalmaz, melynek jelentős része a hazai gyorsforgalmi úthálózat bővítésére irányul.

A gazdasági életben kiemelt szerepet játszanak az autópályák, melynek elérhetőségét a 4. ábra mutatja.

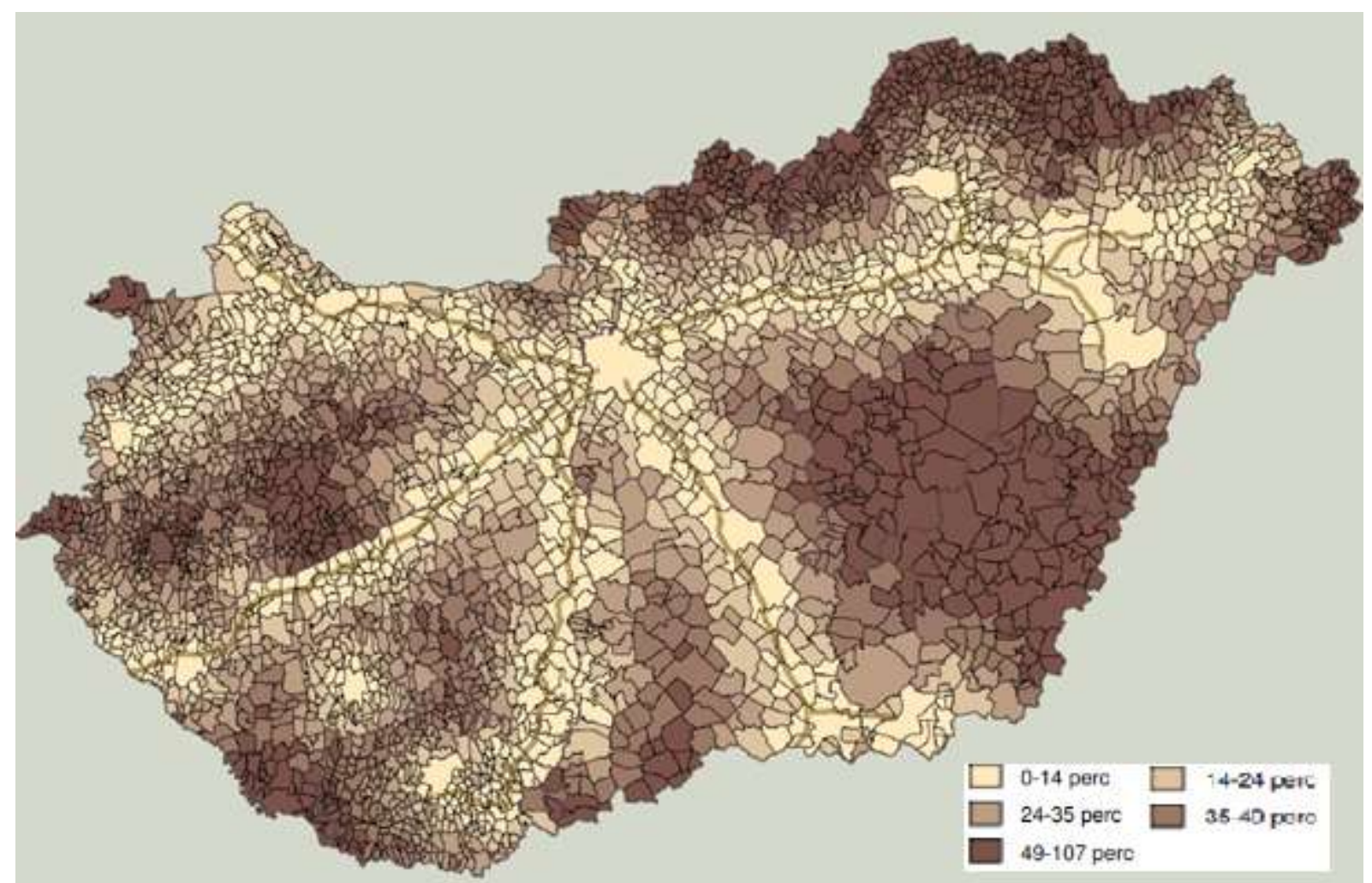

4. ábra: A legközelebbi autópálya csomópont elérhetősége percben, 2016

Forrás: TeIR adatok alapján saját szerkesztés, 2017

Péli (2013) munkájában hangsúlyozza, Magyarország közlekedési hálózata jelenleg is erősen centrális, sugaras jellegü. Ez a szerkezet hátráltatja a vidéki nagyvárosok gazdaságának megerősödését, hiszen a föváros, az ország politikai-gazdasági központja, központi elhelyezkedése miatt az ország jelentős részéröl könnyen elérhető. Ez az állapot nem kedvez a vidéki növekedési központok megerösödésének. 
Osztozunk azon állásponton, hogy a közlekedési infrastruktúra - azon belül is a gyorsforgalmi úthálózat megléte - alapjaiban határozza meg egy térség gazdaságát. Mielőtt részletesen megvizsgálnánk a Modern Városok Program ilyen irányú fejlesztéseit, előtte tekintsük át, mely városok jogosultak támogatásra ebben a programban.

Az elsőként támogatásban részesült megyei jogú városok 2015-től részesülnek ezen forrásokból, míg az utolsó támogatási szerződést 2017 májusában kötötték meg.

Mint az előzőekben ismertettük 23 megyei jogú város található Magyarországon, azonban ez a majdnem két tucat város jelentős differenciálódást mutat. Az 5. számú ábrán szemléltetjük a 23 város népességét.

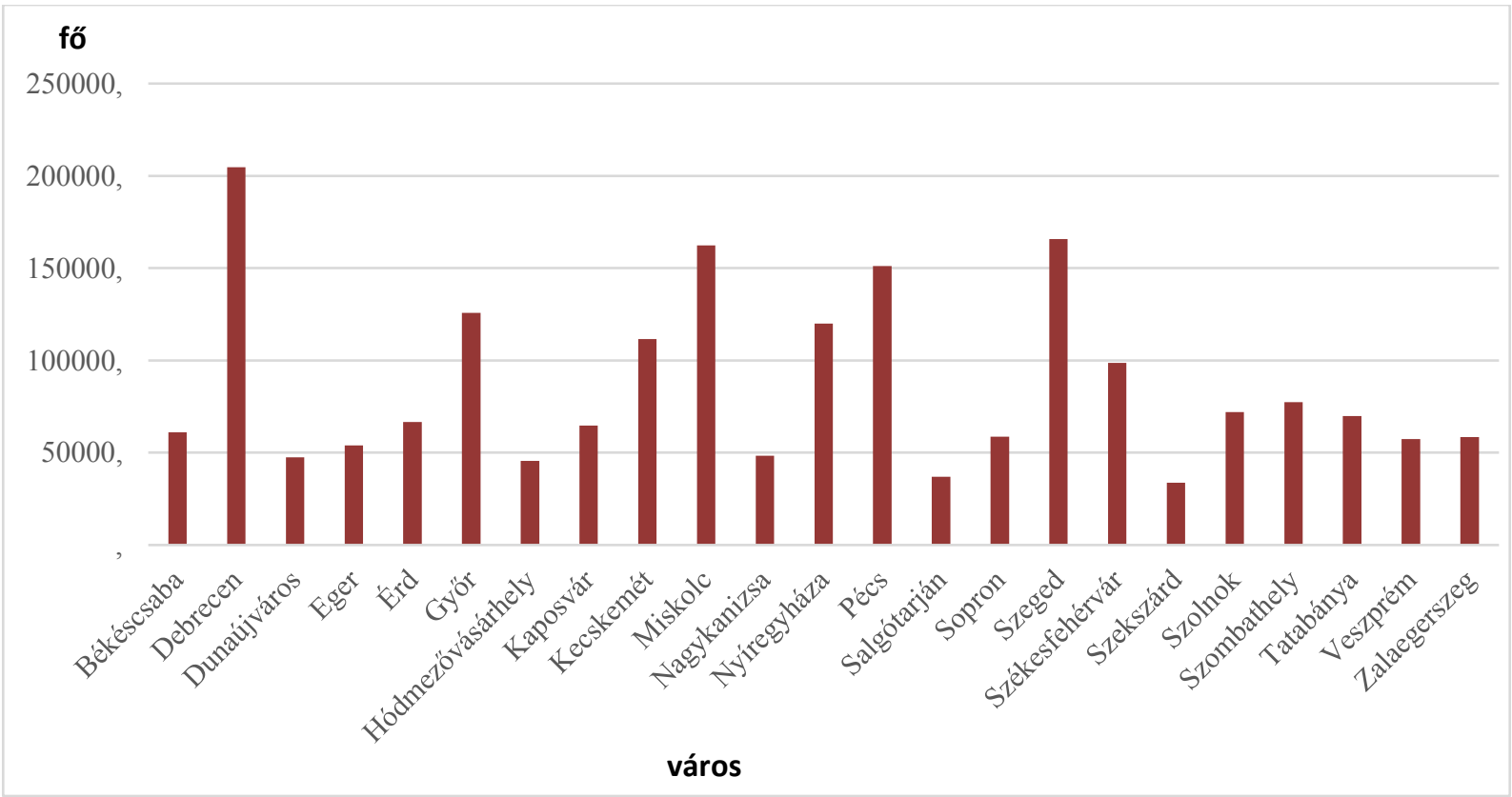

Forrás: saját szerkesztés, 2017

\section{5. ábra: A megyei jogú városok lakónépessége}

A hazai lakosság 19,87 \%-a lakik megyei jogú városokban és ez az adat nem tartalmazza az agglomerációs/agglomerálódó térségeket. Ezekkel együtt $30 \%$-ot is meghaladó értéket kapnánk, akik közvetlenül érintettek ebben a programban. Még tagoltabb a kép, ha a fővárosi lakosságot (17,01\%) figyelmen kívül hagyjuk - hisz a területi különbségek mérséklése nem öket célozza -, mely agglomerációjával együtt szintén jelentős hányadot takar.

Az ábrán látható, hogy az öt jelentős vidéki nagyvárosunkon (Győr, Pécs, Szeged, Debrecen és Miskolc) kívül még Kecskemét, Nyíregyháza és Székesfehérvár rendelkezik 100000 fős, vagy azt meghaladó lakónépességgel. A megyei jogú városok definiálásakor láthattuk, hogy egyik feltétel az 50000 főt meghaladó népesség. Ezen kritériumnak a 2015. évi demográfiai adatok tekintetében öt város nem felel meg: Szekszárd és Salgótarján lakossága a 40000 főt sem éri el; Hódmezővásárhely, Dunaújváros és Nagykanizsa népessége pedig néhány ezer fővel marad el a kívánt határtól. Mivel a megyeközpontok automatikusan megkapják a címet, ezért Szekszárd és Salgótarján mentesül az 50000 fös kritérium alól. A törvény értelmében csak a megyei jogú város cím odaítélésének feltételeit szabták meg, annak elvesztésének módját nem, így amely város egyszer elnyerte a címet, az jogosult is marad arra.

A továbbiakban megvizsgáljuk a Modern Városok Program által az adott megyei jogú városba egy lakosra jutó támogatás mértékét, melynek eredményét a 6 . számú ábrán szemléltetjük. 


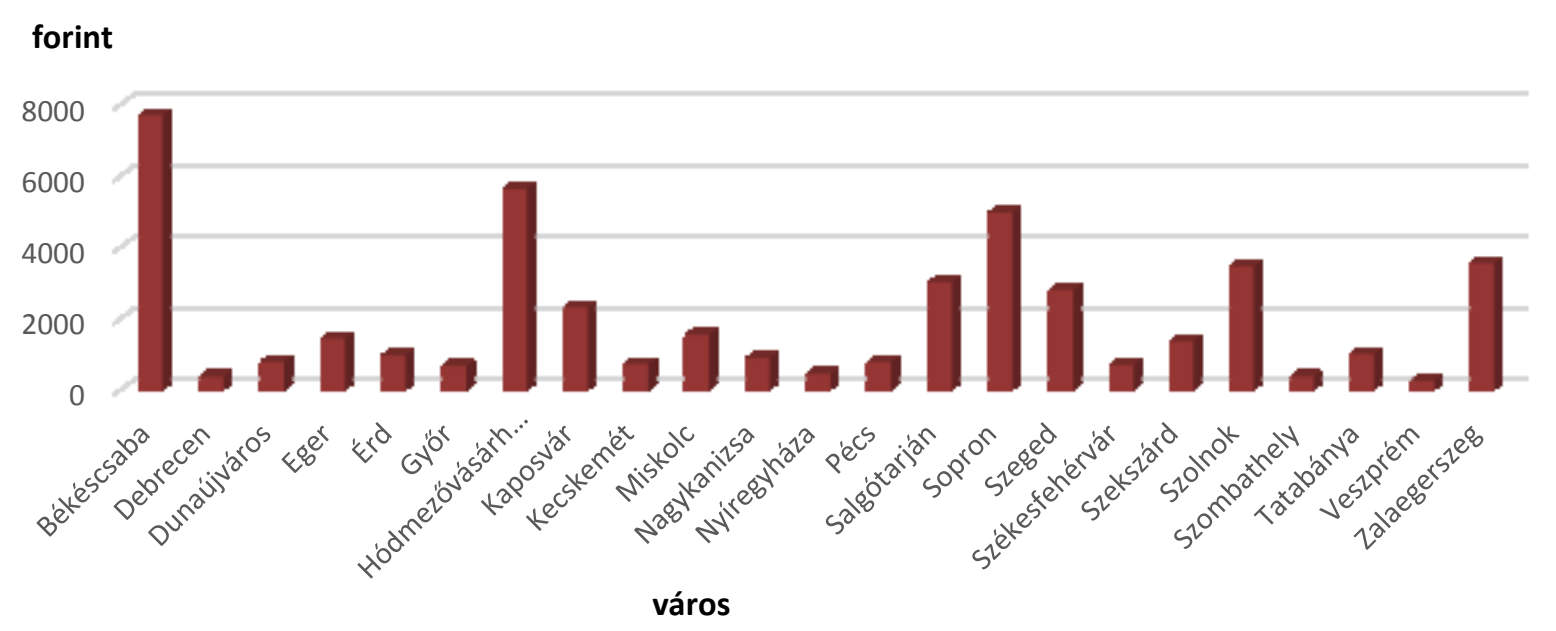

6. ábra: Az egy lakosra jutó támogatás a Modern Városok Programban

Forrás: saját szerkesztés, 2017

Mint az a 6. számú ábrán jól látható Békéscsabán a legmagasabb az egy före jutó támogatás, melynek mértéke meghaladja a 7700 Ft-ot. A támogatás jelentős részét teszi ki az M44-es gyorsforgalmi úthálózat megépítése, mely valóban indokolt, hisz a megyei jogú városok jelentős része már jóval korábban bekapcsolódott a magyarországi gyorsforgalmi úthálózatba, Békéscsaba azonban még mindig nincs összeköttetésben ezzel a hálózattal. Mivel Békés megyét ,az ország éléskamrája”-ként is szokták aposztrofálni, így jelentős támogatás jutott a mezőgazdaság, illetve a feldolgozóipar számára is (hűtőház). A másik két legjelentősebb egy lakosra jutó támogatásban részesülő város Hódmezővásárhely, illetve Sopron. Az előző városban számos infrastrukturális beruházás indul, illetve bővül a város ipari parkja, míg az utóbbi esetében szintén jelentős gyorsforgalmi úthálózat-fejlesztésre kerül sor, megépítik az M85-ös gyorsforgalmi útszakaszt.

A három említett városon felül Zalaegerszeg, Szolnok, Salgótarján részesül még nagyobb mértékü támogatásban, illetve a vidéki öt nagyváros közül - Debrecen, Győr, Miskolc, Pécs, Szeged - közül az utóbbi számíthat a legnagyobb mértékü támogatásra. Ebben kiemelt szerepet kap a közlekedési infrastruktúra-fejlesztés (új közúti-vasúti Tisza híd, M47-es út építése), de a város ipari parkja is jelentősen bővül, valamint városrehabilitációs és sportfejlesztésekre is sor kerül.

\section{Következtetések}

A Modern Városok Program keretében nyújtott 3400 milliárd forint értékủ támogatás a hosszú távú fejlödés záloga lehet számos megyei jogú városunkban. Megvizsgálva a városokra jutó támogatást kitünik, hogy a gyorsforgalmi úthálózat fejlesztése kiemelt hangsúlyt kapott a programon belül. A legjelentősebb támogatásokat (egy lakosra jutó) azon városok kapták, amelyek még nem csatlakoztak a hazai gyorsforgalmi úthálózathoz (Salgótarján: M21, Szolnok: M4, Zalaegerszeg: M76 és M9, Békéscsaba: M44, Sopron: M85 etc.). Mint az korábbi kutatásainkból (Péli, 2013) kiderül, a közúti infrastruktúra minősége jelentős mértékben befolyásolja az adott térség/város fejlettségét, ennélfogva a gyorsforgalmi úthálózat fejlesztését jó iránynak tartjuk. 
Magyarország monocentrikusságát oldani csak a vidéki térségek erősítésével lehet, melynek alapja a vidéki nagyobb városok gazdaságának fellendítése. A pólusokban kedvező területi hatások beindítása, illetve kiterjesztése, ezáltal az agglomerációs folyamatok erősítése, azok dinamizáló hatásainak távolabbi perifériákba való eljuttatása. Az államnak szükséges több pénzt fektetnie a másodlagos pólusokba, mivel a föváros és a vidéki pólusok közötti különbségek nagyok és tovább növekednek. Ahhoz, hogy ezek a nagyvárosok ténylegesen betöltsenek efajta szerepet, szükséges az innovációs folyamatok erösítése, a decentralizáció támogatása. Ehhez adhat kellő alapot a Modern Városok Program.

\section{Összegzés}

A Modern Városok Program egy hatalmas mértékű fejlesztési-támogatáscsomag, melynek során Magyarország Kormánya a megyei jogú városokat támogatja számos területen. A cél ezáltal, felpezsdíteni ezen városok gazdaságát, hogy azok valós centrumai lehessenek környező térségüknek. Fontos megjegyezni, hogy ezen gazdaságfejlesztési intézkedések alapja a megfelelő szintű elérhetőség, amely kedvező közlekedési infrastruktúrát igényel. Az általunk vizsgált program egyik pillére ennek biztosítása a vidéki nagyvárosok részére.

\section{Köszönetnyilvánítás}

\section{고 \\ “AZ EMBERI ERŐFORRÁSOK MINISZTÉRIUMA ÚNKP-17-4 KÓDSZÁMÚ ÚJ NEMZETI KIVÁlÓSÁg PROGRAMJÁNAK TÁMOGATÁSÁVAL KÉSZÜLT"}

\section{Irodalom}

1. Áldorfai Gy.- Czabadai L. (2014): Helyi válaszok a globális kihívásokra Acta Carolus Robertus : Károly Róbert Főiskola Gazdaság- és Társadalomtudományi Kar tudományos közleményei 4 (2): pp. 9-18.

2. Bakos I. - Gerencsér I. (2016): A versenyképesség mérése, In: Szügyi György, Ritter Krisztián, Bakos Izabella Mária, Gerencsér Ilona (szerk.), Kézikönyv a képzési rendszer megvalósítása az önkormányzatok gazdaságfejlesztési feladatainak támogatására. 567 p. Gödöllő: Szent István Egyetemi Kiadó, 2016. pp. 177-186. (ISBN:978-963-269-567-9)

3. Beluszky, P. (2003): Magyarország településföldrajza. Budapest-Pécs: Dialóg Campus Kiadó.

4. Csomós, G. (2010): Területi egyenlőtlenségek Magyarországon: az ESPON*-elemzés adaptálása a tervezési-statisztikai régiók policentrikusságának vizsgálatához. Területi statisztika; 13. (50.) ÉVFOLYAM 2. SZÁM, március , 156-167.

5. Filep, B. (2008): A nagyvárosok versenyképessége és térségszervező funkciói, Doktori értekezés. Széchenyi István Egyetem, Regionális- és Gazdaságtudományi Doktori Iskola: Györ.

6. Lengyel I. - Rechnitzer J. (2004): Regionális gazdaságtan. Budapest-Pécs: Dialóg Campus.

7. Nemes Nagy, J. (2005): Fordulatra várva - a regionális egyenlőtlenségek hullámai. In D. Z.-S. Ferenc, A földrajz dimenziói (old.: 141-158). MTA Földrajztudományi Kutatóintézet: Budapest.

8. Oláh I.- Topa Z. (2016): Accessibility as a factor of small settlements' development, Journal of Environmental Protection, Safety, Education and Management 4:(8) pp. 2837. 
9. Péli L. (2013): Növekedési pólusok föbb regionális gazdaságtani összefüggéseinek vizsgálata Magyarországon, Budapest: Agroinform Kiadó és Nyomda Kft., (ISBN:978-963-502-970-9)

10. Rechnitzer J.- Lados M. (2004): A területi stratégiáktól a monitoringig. BudapestPécs: Dialóg Campus Kiadó.

11. Ritter K. (Szerk.)(2017): Vidékgazdasági tanulmányok. Gödöllő: Szent István Egyetemi Kiadó, 120 p. ISBN: 978-963-269-604-1

12. Salamin G. - Péti M. (2005): Az új Országos Területfejlesztési Koncepció. Falu, Város, Régió , 3-41.

13. Vancsó V (2013): Az Integrált város- és településfejlesztés tervezését támogató alkalmazásról

14. ÚMFT, (2006): Új Magyarország Fejlesztési Programja,Partnerségi egyeztetési változat: A stratégia meghatározása. Budapest.

15. Központi Statisztikai Hivatal weboldala: https://www.ksh.hu/docs/hun/xftp/idoszaki/regiok/veszpremmjv10.pdf

16. Magyarország Kormányának weboldala: http://www.kormany.hu/hu/aminiszterelnok/modern-varosok-sorozat

17. http://www.terport.hu/telepulesek/telepulestipusok/megyei-jogu-varosok 